\title{
Counselling: The Current Opium of the People?
}

\author{
Tony Carton \\ Wellington Institute of Technology, Auckland, New Zealand \\ Email: tony.carton@weltec.ac.nz
}

Received 16 December 2014; accepted 26 March 2015; published 2 April 2015

Copyright (C) 2015 by author and Scientific Research Publishing Inc.

This work is licensed under the Creative Commons Attribution International License (CC BY). http://creativecommons.org/licenses/by/4.0/

(c) (7) Open Access

\begin{abstract}
Western religion's propensity to stultify holiness and the sacred is eclipsed in the profession of counselling. With its fundamentalist enthralment with the individual self, this poster-girl of liberalism, through its central modus-operandi, language has achieved a privileged rhetoric thereby relegating itself to the dustbin of history certainly in Western society. It is less a "sigh of the oppressed soul" (Marx, 1978) as the empowerment of an opportunistic harlotry that energises the profession in a neoliberal marketplace with discourses of social justice routinely cheapened and ideologically hijacked. The author designates a genealogy of this ascendant plummet learnt through retrospective insight. Counsellors have not only unconditionally accepted tablets of stone around truths but also binaries of truths. Interrogating several sacred cows in the profession including the concept of burnout, the should/need dichotomy and the parallel process he apprehends a trajectory chronicling nodal points and concluding that many undertakings within counselling serve increasingly to perpetuate a political-non-political conflation with marketplace morality idealised as liberalism morphs seamlessly into neoliberalism. What descends from a neoliberal paradise are reconfigurations of dichotomies not" of our choosing" (Marx, 1978) but of our own choice. Willingly with the anesthetising of any coherent Judeo-Christian impulses we opt for the sanctity of a vacuous Starbuck spirituality as liberalism or religion in its "degutted" version (Eagleton, 2009: p. 41) enacts the comfort of the afflicted but never the affliction of the comfortable.
\end{abstract}

\section{Keywords}

Neoliberalism, Foucault, Addiction, Resilience, Religion

\section{Introduction}

\section{The Upwards Descent}

The research aim in this article is to interweave micro and macro illustrating how the minutiae of counselling 
interactions serve to exact neo-liberal spirituality by unsuspecting clinicians on unsuspecting clients. In the liberal west counselling has to some extent replaced religion as a means to offer solace. In so doing it serves to anesthetize humans in the same way as Marx alleges ironically religion did in the past. It is hoped that clinicians may problematize the epistemological, ontological and consequently spiritual power of their routine practice.

Simultaneously deflating and inflating passions as new professionals in the addiction counselling field in the early 1990s research (Baker et al., 1997: p. 18) indicated, that the roles we perform were firstly a waste of time, but secondly done rather well. It was discovered that brief interventions were as effective as long term treatment in addressing substance abuse issues. Heather stated "the evidence strongly suggests that many clients do not need... a(n) expensive course". Addressing the usefulness of this he added, naively we now realise, "therapists can devote more time and energy to those with more severe problems" (Baker et al., 1997: p. 18). Pronouncements on social research findings and interventions are never made in a political vacuum particularly when blessed with the mantle of evidence base in a field concerned with distancing itself away from quazi-faith based practices onwards to modernity. Moreover increasingly under conditions where there is, passively what is termed a shrinking health budget only a prophet could have predicted the future. Significantly numerous studies indicated that a brief self-questioning exercise was inherently effective not so much in readying the client to receive treatment for drug abuse but to bring about change by itself. Miller quotes:

"Our expectation that the DCU (Drinkers Check Up) would trigger help seeking was not confirmed "rather it appeared to motivate enduring self-change in drinking” (Miller \& Rollnick, 2013: p. 374).

He added "what began as an interest in motivation for treatment had broadened to a motivation for change" (Miller \& Rollnick, 2013: p. 375). Serendipity combined with an emerging neoliberalism. Thereupon an article of faith materialised in the arrangement of a simulated dichotomy between treatment and change.

Aspiring professionals studiously integrating the dogma of their new profession were subject to the hidden curriculum (Haralambos, 1985: p. 187) implementing this new truth. Inevitably ideal-types emerged recruiting sympathy or disdain as the article of faith for entry to the field. Vocabulary around disease and deficit and therefore treatment were in the process of erasure, jettisoned off, aetiology rendered as an interesting irrelevancy (Todd, 2001). This process was empowered by the clinician's increasing sophistry at sinking into a shared renunciation of community facilitated in various elegant means. This continued despite the fact that as many know, the idea that the intrinsic person can cure themselves is as stable as the proposition that one could tickle themselves.

\section{Trajectory of the Counselling Field-The Hegelian Idealist Mythology}

Reviews of the recent modern addiction discipline would traverse practices like Client Centred Practice (CCP), Cognitive Behavioural Practice (CBT), and Motivational Interviewing (MI) with some wild cards such as family therapy and twelve-step interventions. Common sense would track a modernist teleology shedding comprehensibility on tensions encountered on what we dutifully envisage as a trajectory towards the ideal. An inherent component of progress includes embracing articles of attraction and repulsion alternatively nourishing the observer with self-righteousness then disgust albeit under the guise of a value free science and professionalism. Thesis jars against anti-thesis, then synthesis in satisfying dramas with an intellectual interpretation. New models emerge and as a result new professional disciplines emerge in a satisfying trajectory towards the ideal, at least according to a Hegelian narrative.

Words and concepts, slippery entities at the best of times connote parallel manifestations of this journey. The key concept disease, a word designated at present as contagious, yet at other times liberating excites attraction then repulsion. Understandings of addiction are not inscribed in tablets of stone, often they are by-products of ideological tensions. In modernity understandings around addiction were bounded by a triumvirate (see Figure 1). The religious dynamic (moral) was eclipsed by the emerging dynamic of science (medicine). Obscured were radical changes in the relationships of production (monetary). Within the region of this triangle tensions structure our words, thoughts, feelings and actions in late capitalism.

In such an environment conflation occurs simultaneously with dissimilarity. Words with myriad connotations such as sobriety or moderation/abstinence from alcohol, moral uprightness and strong willpower are moral yet political. Conflations of protestant and capitalist discourses produced various ideal types enlisting both admiration and disdain. These discourses functioned to perpetuate emerging relationships of production. May (2001) 


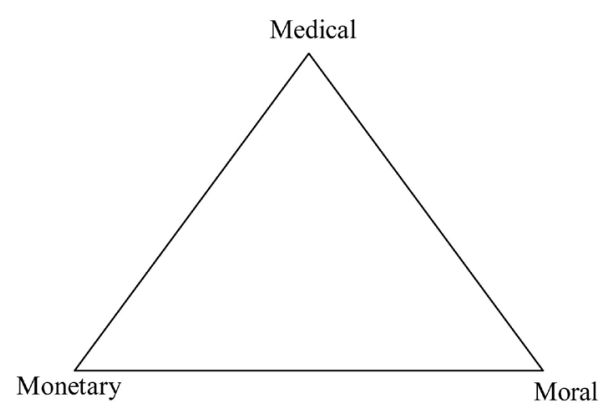

Figure 1. A modern episteme of addiction.

describes how understandings of addiction ensued from the social dislocation caused especially due to the Land Enclosure Acts of the sixteenth seventeenth centuries by which land in England hitherto owned by Divine Right, under stewardship of the gentry, was effectively privatised under a new egalitarian regime divesting it away from hitherto communally farmed land. Peasants were thus driven off the land, creating fodder for the mills and the armies of colonization. Surplus populations not readily appended into these categories presented to the workhouse under the watchful eye of a compassionate though proselytising evangelical. In situations where there is major upheaval religion inevitably presents as a comforter or harbinger of meaning for peasant and lord.

However not for the first or last time the egalitarianism which eventually culminated in democracy and universal suffrage obscured a reductionism to economy rather than the optimism provided by a vulgar Hegelian idealism. This conflation of neoliberalism and religion is best seen in eighteenth century Ireland, England's first and most troublesome colony. Monetary and morality discourses morphed in an early version of neoliberalism in all its honest brutality known as providentialism (Coogan, 2012: p. 35). This version of political economy empowered the Whig government in England to rejoice in silence as God visited a famine on the Irish with Governor Trevelyan railing against intervention pleading "not turn into a curse what was intended for a blessing" (Coogan, 2012: p. 97).

\section{Recent Developments: Original Sin Deleted}

On the path to modernity the moral model eclipsed by the dispositional model was only then to be eclipsed by psychodynamic and cognitive behavioural models. These had commonalities (notably a focus on the individual self) but also countered preceding models. The moral model stressed narratives around sin, the addict perceived as culpable May (1997), but was countered with the dispositional model stressing biological susceptibility. This was then upturned by Freud stressing unresolved sadness only then to be upset by the behaviourists in reinstating madness as a result of dysfunctional learning.

The client/clinician relationship rules of engagement, too mundane for comment apart from sociological discourses received scant attention. The client had a Parsonian sick role (Millon et al., 1999) the professional a helper's role. In short the client/ patient (soon to be consumer) had, to put it bluntly, something wrong with them being sad, mad, or bad.

The Hegelian teleology seemed inescapable. Moral, dispositional, psychodynamic, behavioural ideals each built on yet, opposed the previous one onwards into glory or enlightenment or self-actualisation. Moreover evidence, albeit at times manufactured, supported each model. The idealist mythology was inescapable, inevitable, but as with many things that are inescapable and inevitable it was misplaced.

For many clinicians on the ground floor despite their misgivings it would be wrong to say that they are getting worse at their jobs. But it would be right to say that it would be very foolhardy to make that assertion and so collectively they do not. And so they exist in a collective malaise born of alienation.

A cursory review at the recent trajectory would cite CCP then CBT then MI in a seamless uninterrupted progress. MI builds on the strengths and weaknesses of CCP and CBT. MI in its claim to be client centred but therapist directed (Miller \& Rollnick, 2002) is refreshingly honest in its panoptic implications (Foucault, 1977). This is business as usual yet profound in its impact.

MI is radically different from other practices in that:

It is

1) Strength based 
2) Non Aetiological

3) More an interview than counselling intervention

4) A minimal intervention.

A critical review of this trajectory would surface alternative themes rather than unequivocal progress.

The progress that results is of an increasing "tyranny of distance" (Split Enz, 1982) CCP is long term, the clinician somewhat of a guru of mystique plumbing the depths of the (albeit highly secular) soul is intense with no finite end. In CBT the end goal is to teach the students to teach themselves. The imagined sophisticated fine tuning of professional competence can also be seen as a distancing of the clinician away from the client. Traditionally addiction clients are over whelmingly treated by state intervention, although this is dwindling through an ideology of state retraction Dean (1999).

Marx upset the cosiness of the Hegelian dialectic idealism with the cold hard proposition of dialectic materialism (Giddens, 2002). Progress is not predicated on ideals which in any case are predicated on material conditions. Neoliberalism in all its gross materiality determines our ideals consciousness, moralities and also the conditions of possibility for these.

Furthermore the comfort of progress and continuity also gets tossed into vehement disarray with the genealogy of Foucault (1978), and the clean archaeology of common sense looks like an immature ideology. The tensions, dichotomies that structure our thoughts and feelings, (better understood as discourses) when we are honest about it afford us insights into our own spiritual redundancy. Produced are debates but also the terms and terminology of the debate. Moreover the progress that exists is not predicated on striving towards a heavenly ideal but a blind submission to the entity known in ancient terms as Mammon but in more enlightened times as political economy, providentialism and today as market liberalism. Motivational Interviewing behaves like a progressive colonising project not destroying indigenous practices, but empowering them to serve as apparatuses of indigenous self-colonisation. The client freely becomes an active self-colonising subject under the loving gaze of a distant consultant with an hourly charge out rate. There is no cathartic release from a deficit or original sin or the character defects of AA (Alcoholics Anonymous, 1976) just a willing and rational supplication to Neoliberalism. The interminable debates over the aetiologies of addiction, be it badness, madness or sadness are resolved by changing the terms of engagement and the relegation of aetiology into obsolescence. This is not because of the limitations of aetiology but because of wider structural concerns outside the ambit of psychology, although the discipline has been enrolled into abbeting with its function as the chiropractor of the psyche Eagleton (2012: p. 16). In short MI has become a management tool based on an aggressive worship of the individual self. Traditional Judeo Christian and Islamic discourses around selflessness, submission and humility are rendered as primitive acts.

\section{The Should/Need Binary}

Newton and Descartes (Armstrong, 2009) constructing their elegant proofs (thereby subverting St Thomas Aquinas) for the existence of God inadvertently produced the conditions of possibility for the proof that there was no God. New battle lines and vocabularies emerged into modernity. Cognitive/intellectual prowess placed firmly on the moral agenda, the reality of God/Religion became a bourgeoisie intellectual pastime, thereby casually excluding the naïve unwashed classes who mundanely accept that what we cannot understand often provides a tangible structure for living and dying.

Anticipating the inevitability of how modernity and liberalism would dissolve into a neoliberal soup Foucault (1980) promulgated the panapticon metaphor. In neoliberal society freedoms from enslavement are traded democratically and rationally for the sovereignty to self-enslave. Jeremy Bentham's panapticon (Foucault, 1977) in the prison system produced prisoner/captive interactions ostensibly based on egalitarianism, rationality and progress but ultimately economic forms of control, and indeed self-control. The economy of scale available to prison authorities so that many prisoners were accessible to surveillance with one tower paralleled the economy of scale by prisoners in compliance. At any time they could be under the gaze of the authorities. For the prisoner the most reasonable behavioural strategy involved assuming the reality of the unseen, albeit a figure of a man (possibly) in the tower. Surveillance/compliance formed an eloquent dialectic that obscured political economy behind a façade of egalitarianism. Rules of domination were internalised through a rigorous rationality, the watchtower dispensed super-egos to the incarcerated flock. This pervasive structure proceeded unproblematically unless the prisoner was political and railed about the suffocating effect of internalised repression. There are 
notable names like Nelson Mandela, Mahatma Ghandi or Bobby Sands or in the worst case the notorious Jesus Christ.

Despite and maybe because of progress humans in the western world now busy themselves in various apparatuses of their own subjugation almost to a spiritual degree. And in so doing this they employ the vocabulary of the counselling profession. They refer to how they feel rather than think, that other people need to not should. The priests work dispensed with the counsellor ironically emerges with implements of rationality having through professionalization jettisoned affective and traditional knowledges and seamlessly chosen marketplace vocabularies in an area where science is as indistinct as ethics.

Current models zealously eschew judge-mentalist moralising the language deficit free to a fault.

Clinicians never say to a client you should do something about... They say you need to do something...

With the should interaction there is a parent to child issue, and the clinician is making a judgement on what is right for the individual. This is seen as counter-productive, even morally wrong. The controlling parent will evoke the rebellious child. However even in the resistance against should there is a dignity. A preferred interaction is you need to. This is envisaged as more egalitarian and democratic. There is hence no dignity to be achieved by resistance against such a display of egalitarianism .But it could be questioned who decides what an individual's needs are? Are they the internalised effects of a panoptic arrangement in counselling?

\section{Burnout}

Often when teaching addiction professional practice class, I witness a secular apparition. I attend a very ingrained ritual I have seen many times when I am reminded of the comment by Karen Armstrong (2009) around myths to the effect that they (myths) may or may not be true, but they continually happen. It is the continued recital of them that accomplishes their veracity.

This reasonably sophisticated and experienced class are requested to present on a particular case in their clinical placement in which they experienced serious challenges. Throughout the presentations I notice yet again a theme, a familiar dance and rhythm in the voices. Harmony at the start then cacophony, in the middle and near the end a resolution like resignation to the inevitable, eye contact being more often used at this stage as a signifier of approval. In every example the most difficult aspect of the case cited was never the direct client issue or behaviour but structural issues in the service inevitably due to funding shortages, lack of resources, inconsistent management and overwork. Despite this stated prioritisation these are addressed near the end in peripheral grades of conversation, the active voice dissolving into the passive tone. Inevitably the solution entailed was a recital of what acts as a prayer in the field, the concept of Burnout (Figure 2).

This list has a pragmatic spirituality more significant in its recital than its practicality .Acting as an apparatus of alienation it endorses professionals to simultaneously address and ignore problems empowering them to "squat outside the universe, offer it up as the ideal" (Marx, 1978: p. 54).

Figure 21 shows 12 (a magical number) responses to Burnout are outlined. I have problematized them albeit

\begin{tabular}{ccc}
\hline no & Suggestions & Class Responses \\
\hline 1 & Recognise and own the symptoms & I do that every day \\
2 & Talk with someone about your feelings & I do that every day \\
3 & Reschedule your work & I do not have the authority \\
4 & Cut down on your workload & I,ll get fired \\
5 & Take a holiday & I have used up all my leave \\
6 & Use relaxation or meditation & I do that every day \\
7 & Use positive self-talk & I do that every day \\
8 & Lower your expectations of yourself, clients, colleagues and employer. & They could not be any lower, especially of my employer \\
9 & Allow yourself to enjoy life and have a sense of humour & You mean black humour \\
10 & Use thought stopping to stop worrying about clients when not at work & I do that every night \\
12 & Use your religious or other belief systems for support & So is my spirituality at fault
\end{tabular}

Figure 2. Suggestions to combat Burnout. Gilberd, D. \& Gilberd, K. (2001). Basic personal counselling. Malaysia: Prentice Hall. 
hesitantly because they have assumed a spirituality and an understanding of their impracticability that reinforces holiness.

But in summary they would probably produce burnout rather than alleviating it. They conflate symptomology and aetiology and position them within the worker. They are patronising and insulting of beliefs outside of a neoliberal framework. If they were transcribed into Latin a combination of incomprehensibity and impossibility would add to their aura of spirituality.

Blue collar workers never had access to this entity which involves a highly sophisticated category of collective spiritual inaction, metaphysics effective by repetition rather than applicability. The list has a pragmatic spirituality more potent in its recital than its usefulness. There is a collective knowingness that the recommendations are impossible. However the ritual becomes powerful not despite but due to this.

In the exercises it was observed that practitioners looked around at each other for sympathy and approval then validation a resolution based on a resignation had been reached. It was a like when a bored child hears the musicality of the priest saying "the Mass is ended go forth in peace". However there was no doubt that it all worked, the general mood seemed to lift .A devout atheist watching the ceremony would have had their disbelief confirmed.

\section{Parallel Process}

Counsellors rightly in their training take great care around the concepts of do no harm, non-maleficence and beneficence (DAPAANZ, 2005). Like good professionals they are concerned about harm caused by doing their job badly, but no attention is focussed on the harm that is done when their job is done well. That is of course when the original vocation of the profession has been subverted by neoliberal ethics albeit with a spiritual tinge. Much attention in clinical supervision is involved in attending to the perils of malpractice especially in the realm of parallel process (Gilberd \& Gilberd) where the client identifies the clinician as a previous significant other in their lives (transference) or where the clinician sees client as a previous significant other (counter-transference). Often this is an unconscious matter and can lead to the disruption of clinical efficacy or even harm. The playing out of sexual needs are often the most feared. A very apt supervision question is "in this counselling relationship whose needs are being met? Is it the clients (as it should be) or the counsellors (as it should not be) .When it is the latter, it would be safe to say that something is being done wrong or unethical. More problematic and invisible is the scenario when is that both needs are not being met due to best practice rather than malpractice. This unaddressed issue is an invisible unconscious phenomenon better understood as alienation. Over the last ten or so years the discipline of counselling has been forced into a "dalliance with an alien thing" (Yeats, 1976) or more accurately several alien things firstly medicalization, secondly neoliberalism. This requires a sophistry on the part of addiction clinicians. At the periphery medicalization requires compliance to medication, addiction treatment requires clients to desert their chosen medication. The market model requires providing the consumers with what they want, the addiction clinician provides the client with what they don't want, that is the abrupt dislocation of, physical, emotional and spiritual dependency. As such the clinician must on a normal day in the words of Henry James "have an extreme respect for (her) their own motives" James, 1954: p. 34) The tabloid motives such as sexuality are adequately catered for under ethical requirements but there is a mystical silence over structural issues. The worrying parallel process is the unaddressed distribution of a superego on an unsuspecting flock .As one author states "counselling itself will reflect the political ideas of the present" (Kearney, 2009: p. 88). Kearney understates the issue, given the insights of Foucault (1988) we know now that as clinicians we recreate these cirizens and thus alienate themselves away from their social selves as well as ourselves more efficiently than does religion.

\section{Discussion}

Currently in the west religion is understood "as a set of doctrinal opinions rather than a commitment" (Armstrong, 2014: p. 222).

Traditionally religion has existed in varied relationships with the state alternatively as an instrument of repression or liberation. In the Irish Famine; forms of Protestantism were used to sanctify the starvation of the indigenous Irish, in the US southern states the same faith helped to liberate the black population. This uneasy marriage culminated more in guilt than admiration by association and thereby in the west religion was rendered into redundancy. 
Religion in its earlier forms was humanity’s first methodology for making sense of the world. Garfinkel in an experiment on counselling taking a step away from Freud demonstrated how meaning is created within the counselling interaction, the client "imposing order where no order existed" (Haralombos, 1985: p. 555). Counselling as a "surrogate of religion" (Eagleton, 2009: p. 40) had an unspoken function in society in helping people to conform to societal roles. According to Parsons (Haralombos, 1985) the client fulfilled a sick role, the clinician the helper role a relationship almost too mundane for comment.

But now counselling arrives at the same redundant destination, clients are not sick, diseased or in deficit. Therapeutic strength based practices are geared not to releasing a true self in order to be a functioning member of society but in fabricating subjectivities amenable to a disappearing state. It is a conflation of idolatry and alienation ensuing a rigorous love affair with a divided self, consecrated in the church of the free market.

The psy-sciences during the enlightenment partly toppled religion at least in its role as provider of consolation. Marx’s famously misrepresented statement that religion was the "opium of the people (Haralambos, 1985: p. 460) provides a self-righteous mantra for fundamentalist secularists who have divested themselves of religion and interestingly in some cases their Marxism in a rush to avoid the sins of essentialism. Parables around the end of the meta-narrative have supported this wholesale abandonment of anything that vaguely looks like a truth claim. Even though it is inherently absurd to state that there is so truth in that the statement collapses upon itself this is the default position among western intelligencia. Currently the nearest people in the West get to any semblance of religion is in counselling where it has descended to a New Age "caricature of the spiritual one would expect in a materialist civilisation to produce” (Eagleton, 2009: p. 40).

Humans, intrinsically part of this world have developed a sophistication in deserting the world and themselves. This historically allegedly has been abetted by religion at least in its more anaemic forms since the Descartian onslaught when the cognitive displaced the active. In late modernity this process continues with" surrogates of religion” (Eagleton, 2009: p. 40) such as counselling. Counselling though often misrepresented as a totally individual act, traditionally in the addiction field is often based on subversion .Addiction often theorised as an impacted system involving substances, people and power ,the therapeutic process involves problematizing unwritten rules and roles and providing empowerment to disrupt these. These rules are sustained by a disconnection between reality and appearances, concepts updated into modernity by Freud as denial, projection, minimising or in colloquial terms known as lying. The goal of much counselling is to enable the client to arrive at an awareness of these.

This involves the addressing of pain when physical, mental, emotional and spiritual homeostatic conditions are cracked, events evocative of the dark night of the soul, the Gethsemane hour or the notorious rock bottom. The coming to the point of recovery is comparable to a newly arrived political refugee in an alien landscape, confused and scared but maybe hopeful, not the budding entrepreneur clenching a successful business deal. Introducing neoliberal rhetoric around goals/plans and achievement at a point like this is at best patronising and at worst insulting. Yet intercessions such as these are becoming the current recommended practice under the non-clemature of resilience. Neoliberalism is well versed in the value of resilience but voiceless at to its price as long as it is borne by the sufferer. Addiction clinicians often complain of losing their soul in the encroaching alienation of the professional process, listing the increasing medicalisation, bureaucratisation and the pervasive fiscal imperatives but they seldom have access to Marxist vocabularies around alienation, Weberian warnings around rationalisation nor are they encouraged to consider client distress as a result of anomie rather than individual defectiveness.

Traditionally counselling worked through confessional like apparatuses influenced by biblical concepts "the truth shall set you free” (Holy Bible, 1987) resulting in processes of catharsis. Subjectivity, or its former version the soul, was seen as having been repressed, the role of counselling to remove this repression and so attain an essential truth. However Foucaultian theory inverting this proposes a subjectivity that is produced (Foucault, 1978) rather than released. This idolatrous production is the outcome of power networks within the counselling interaction. Rather than liberation there is enslavement, the ancient meaning of addiction (Fingarette, 1990). Rather than accessing an inner soul the outcome is the internalisation of a subjectivity conducive to the current neoliberal environment. Larner (2009) gives a good exposition of the components of neoliberalism through the use of governmentality which include subjectivity creation, paradox and state retraction.

As professionalization develops clinicians increasingly construct the client group and facilitating government at a distance "the citizen [client] is represented as an active agent both able and obliged to exercise autonomous choices" (Larner, 2000: p. 11). This freedom is very much inscribed by the power/knowledge nexus of the field 
that determines what clinician and client will bring into discourse. Tendencies to backslide or "go into denial" will be met with a silence: as clinicians roll with resistance. A raft of tools, such as the Readiness to Change Questionnaire (RCQ), articulates the obligation to be free.

Some time ago I witnessed the vitriolic reaction of a western liberal as he listened to an Egyptian woman explaining her wearing of the niqab as she proclaimed that she knew it was not in the Koran, was totally her own choice, no man had told her to wear it .But it was an act of submission to God taken by her willingly. It was fascinating to watch the humiliating descent of western liberal supremacy in response to an act that freely combined submission and defiance denaturalising the customary western corralled understandings of these terms. Even a lapsed Irish Catholic could see that.

\section{Conclusion}

In the vociferous liberal anti-religious west, a key surrogate has arisen to fill the vacuum of religiosity in the form of counselling. However, counselling is evolving as a vibrant agent of alienation, perhaps more so than religion ever did. Religion at times has comforted the afflicted, but also afflicted the comfortable in fighting injustice. Maybe western liberals should cease to project their religophobia on other non-western cultures and consider what they have discarded in the onslaught of modernity.

\section{References}

Anonymous, A. (1976). Alcoholics Anonymous ( $3^{\text {rd }}$ ed.). New York: Alcoholics Anonymous.

Armstrong, K. (2009). The Case for God.

Armstrong, K. (2014). Fields of Blood. Religion and the History of Violence. London: Bodley Head.

Baker, A., Sellman, D., Robinson, G., Mc Cormick, R., \& Dore, G. (1997). The Long and the Short of Treatment for Alcohol and Drug Disorders: Christchurch School of Medicine. Christchurch.

Bible, H. (1987). John 32. Dallas, TX: Thomas Nelson.

Coogan, T. P. (2012). The Famine Plot, England's Role in Ireland's Greatest Tragedy. England: Palgrave Macmillan Basingstoke.

DAPAANZ (2005). www.dapaanz.org.nz/code-of-ethics/

Dean, M. (1999). Governmentality, Power and Rule in Modern Society. London: Sage Publications.

Eagleton, T. (2009). Reason, Faith, and Revolution, Reflections on the God Debate. Yale: Yale University Press.

Enz, S. (1982). Six Months in a Leaky Boat. Melbourne: Mushroom Records.

Fingarette, H. (1990). Alcoholism: Can Honest Mistake about One’s Capacity for Self Control Be an Excuse? [Electronic Version]. International Journal of Law \& Psychiatry, 13, 77-93.

Foucault, M. (1977). Discipline and Punish: The Birth of the Prison. Harmondsworth: Penguin.

Foucault, M. (1978). The History of Sexuality, Vol. 1: An Introduction. Harmondsworth: Penguin.

Foucault, M. (1980). Power/Knowledge. In C. Gordon (Ed.), Selected Essays and Other Writings. Brighton: Harvester Press.

Foucault, M. (1988). Technologies of the Self. In L. Martin (Ed.), Technologies of the Self. London: Tavistock.

Giddens, A. (2002). Sociology. Oxford: Polity Press.

Gilberd, D., \& Gilberd, K. (2001). Basic Personal Counselling. Malaysia: Prentice Hall.

Haralambos, H. M. (1985). Sociology Themes and Perspectives. Bungay: University Tutorial Press.

James, H. (1954). Portrait of a Lady. London: Penguin Classics.

Kearney, A. (2009). Counselling, Class and Politics: Undeclared Influences in Therapy. Manchester: PCCS Books.

Larner, W. (2000). Neo-Liberalism: Policy, Ideology, and Governmentality (Electronic Version). Studies in Political Economy, 63, 5-25.

Marx, K. (1978). A Contribution to the Critique of Hegel's Philosophy of Right: Introduction. In R. C. Tucker (Ed.), Marx-Engels Reader (pp. 53-54). New York: W. W. Norton and Company.

May, C. (1997). Habitual Drunkards and the Invention of Alcoholism: Susceptibility and Culpability in Nineteenth Century England (Electronic Version). Addiction Research \& Theory, 5, 169-187. http://dx.doi.org/10.3109/16066359709005258

May, C. (2001). Pathology, Identity and the Social Construction of Alcohol Dependence (Electronic Version). Sociology, 35, 385-401. http://dx.doi.org/10.1177/S0038038501000189 
Miller, W. R., \& Rollnick, S. (2002). Motivational Interviewing: Preparing People for Change (2nd ed.). New York: Guildford Press.

Miller, W. R., \& Rollnick, S. (2013). Motivational Interviewing: Preparing People for Change (3rd ed.). New York: Guildford Press.

Millon, T., Blaney, P., \& Davis, R. (1999). Oxford Textbook of Psychopathology (p. 446). Oxford: Oxford University Press.

Todd, F. (2001). Co-Existing Substance Use and Mental Health Disorders. Christchurch: National Centre for Treatment Development.

Yeats, W. B. (1976). Selected Poetry. London: Macmillan. 